"INTISARI JURNAL"

\title{
SUNGAI DALAM PEMAKNAAN MASYARAKAT PEDESAAN STUDI ETNOEKOLOGI KOMUNIKASI PADA MASYARAKAT DESA KARANG ANYAR, BANYUASIN, SUMATERA SELATAN
}

\author{
WELLY KUSUMA \\ 1910701004 \\ KOMUNIKASI LINGKUNGA \\ ILKOM A 2019
}

Dikutip dari Dinamika Hidrosfer (2018), sungai adalah aliran air permukaan yang berbentuk memanjang dan mengalir secara terus menerus dari hulu ke hilir. Arah aliran sungai sesuai dengan sifat air, dari tempat tinggi ke tempat rendah. Sungai bermula dari gunung atau dataran tinggi menuju ke danau atau lautan.

Kedekatan hubungan masyarakat dengan lingkungan alam khususnya sungai adalah fakta yang tidak terbantahkan. Sejak dari adanya masyarakat di sebuah wilayah, bisa dipastikan tanda-tanda dan ciri-ciri alam sudah dipahami dan dipelajari oleh kelompok tersebut. Terutama sekali bagi komunitas masyarakat tradisional, tanda-tanda yang datang dari alam bahkan diaplikasikan dalam berbagai bentuk ritual dan tradisi. Penelitian ini dilakukan dengan tujuan untuk menekankan masyarakat dalam memberi pemaknaan terhadap lingkungan alam. yang memiliki ragam aplikasi dalam masyarakat.

Dalam jurnal ini subjek penelitiannya adalah Penduduk Desa Karang Anyar, Banyuasin dan secara secara metodologis penelitian ini menggunakan metode kualitatif dengan pendekatan etnoekologi komunikasi. Peneliti melakukan pengamatan, wawancara, dan berdiskusi dengan berbagai tokoh masyarakat yang ada di Desa Karang Anyar.

Hasil penelitian ini menunjukkan bahwa pemaknaan masyarakat terhadap lingkungan sekitarnya, khusunya sungai. dapat diidentifikasi sebagai berikut :

1. Makna terhadap sungai, bagi masyarakat Karang Anyar sungai adalah urat nadi kehidupan. 
"Sungai juga disebut oleh masyarakat Karang Anyar sebagai Batang Hari, di beberapa istilah lain disebut Laut. Penyebutan Batang Hari menunjukkan makna yang identik dengan sumber kehidupan, yaitu sesuatu yang menentukan harihari dalam hidup ini. Batang adalah penopang dan tiang tempat berdiri, Batang Hari adalah tiang kehidupan itu. Sementara istilah ,laut" bisa dimaknai sebagai wilayah sungai yang memang luas, besar dan dalam. Laut memiliki sumber kekayaan yang sangat banyak, dan itu diidentikkan dengan sungai." (Yenrizal, $2016: 126)$

2. Makna terhadap wilayah sempadan sungai. Wilayah ini adalah wilayah yang berada dipinggiran sungai atau bibir. Tempat ini dianggap sangat strategis karena menjadi pintu utama untuk langsung berhubungan dengan sungai.

3. Makna terhadap pemukiman. Pemukiman merupakan areal yang dibangun khusus untuk perumahan warga. Desa Karang Anyar memiliki konsep pemukiman yang unik, yaitu memanjang sepanjang aliran sungai

4. Makna terhadap sumber mata pencaharian. Di Desa Karang Anyar terdapat dua mata pencaharian utama yaitu, bersawah dan mencari ikan.

Makna ini tidak hanya semata-mata makna simbolik, tetapi diwujudkan dalam bentuk tindakan nyata. Inilah yang dikatakan dalam konteks komunikasi, bahwa simbol melekat pada sebuah benda dan maknanya bersifat sembarang sesuai konteks masyarakat.

Sebagaimana yang dikemukakan oleh Littlejohn dalam (Yenrizal,2016) bahwa secara kultural, komunikasi menghargai dan memandang aspek makna budaya sesuai konteks masyarakatnya. Sedangkan dalam perspektif interaksionisme simbolik menunjukkan bahwa makna simbolik itu selalu dimaknai dan dipertukarkan oleh kelompok yang dimaksud. bisa dikatakan bahwa bagi masyarakat Karang Anyar, sungai adalah pusat kehidupan.

\section{Kesimpulan}

Sungai bagi masyarakat Karang Anyar dimaknai sebagai identitas, batang hari (sumber kehidupan), dan keutuhan kehidupan. Makna ini melekat sejak dari anak sampai orang tua dan kemudian terwujud dalam berbagai rutinitas yang dilakukan.

Yenrizal, Y (2016) mengatakan etnoekologi komunikasi masyarakat Karang Anyar terhadap sungai, menciptakan aspek fungsional kehidupan yang semuanya bersumber dari sungai, 
terlihat dari berbagai fungsi seperti transportasi, persawahan, perkebunan, perikanan, sempadan, dan pemukiman.

\section{DAFTAR PUSTAKA}

Yenrizal, Y. Sungai Dalam Pemaknaan Masyarakat Pedesaan Studi Etnoekologi Komunikasi Pada Masyarakat Desa Karang Anyar, Banyuasin, Sumatera Selatan Yenrizal Universitas Islam Negeri Raden Fatah Palembang. Nizham Journal of Islamic Studies, 5(2), 119-130.

https://e-journal.metrouniv.ac.id/index.php/nizham/article/view/911 